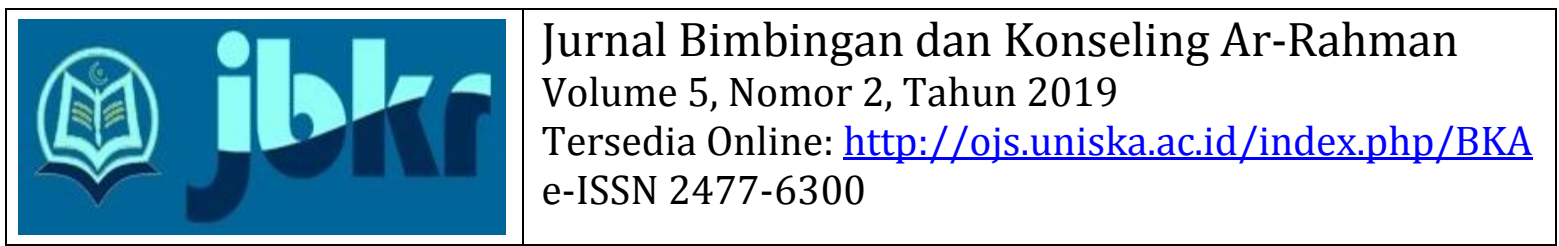

\title{
ANALISIS TRANSAKSIONAL DALAM SETTING KELOMPOK
}

\author{
Yuda Syahputra $^{1 *}$, Neviyarni ${ }^{2}$, Netrawati $^{2}$, Yeni Karneli $^{2}$, Hariyani $^{3}$ \\ ${ }^{1}$ Department of Guidance and counseling, Universitas Negeri Padang, Indonesia \\ ${ }^{2}$ Faculty of Science Education, Universitas Negeri Padang, Indonesia \\ ${ }^{3}$ Guidance and Counseling Program, Madrasah Tsanawiyah Negeri 3 Medan, Indonesia \\ yuda@konselor.org
}

\begin{abstract}
ABSTRAK
Tujuan pada penelitian ini adalah untuk menganalisis terapi transaksional dalam seting kelompok. Analisis transaksional pada mulanya direncanakan sebagai suatu bentuk treatment kelompok dan prosedur-prosedur terapeutik yang memberikan hasil dalam setting kelompok. Jenis penelitian ini adalah penelitian kepustakaan, yaitu serangkaian penelitian yang berkaitan dengan metode pengumpulan data perpustakaan, atau penelitian yang objek penelitiannya dieksplorasi melalui berbagai informasi perpustakaan (buku atau jurnal ilmiah) yang membahas tentang analisis transaksional dalam seting kelompok. Konsep dan teknik Analisis transaksional efektif diterapkan dalam sesi konseling kelompok. Analisis transaksional menyediakan pendekatan terstruktur yang memungkinkan anak-anak dan remaja untuk melihat hubungan antara apa yang mereka pelajari dalam keluarga mereka dan sikap mereka terhadap orang lain.
\end{abstract}

Kata Kunci: Konseling Kelompok; Analisis Transaksional; Ego State

\begin{abstract}
The purpose of this study was to analyze transactional therapy in group settings. Transactional analysis was originally planned as a form of group treatment and therapeutic procedures that gave results in group settings. This type of research is library research, which is a series of studies related to library data collection methods, or research whose object of research is explored through various library information (books or scientific journals) that discuss transactional analysis in group settings. Concepts and techniques of transactional analysis are effectively applied in group counseling sessions. Transactional analysis provides a structured approach that allows children and adolescents to see the relationship between what they learn in their families and their attitudes toward others.
\end{abstract}

Keywords: Group Counseling; Transactional Analysis; Ego State

Dipublikasikan Oleh :

UPT Publikasi dan Pengelolaan Jurnal

Universitas Islam Kalimantan Muhammad Arsyad Al-Banjari Banjarmasin 
Yuda Syahputra, Neviyarni, Netrawati, Yeni Karneli, Hariyani

Jurnal Bimbingan dan Konseling Ar-Rahman

Volume 5, Nomor 2, Tahun 2019

e-ISSN 2477-6300

\section{PENDAHULUAN}

Hakikat Konseling dalam pendekatan Analisis transaksional yaitu perancangan status ego klien dalam bertransaksi sehingga klien mampu mempromosikan dirinya dengan tepat, serta berupaya untuk merangsang rasa tanggung jawab pribadi klien atas tingkah lakunya sendiri, pemikiran yang logis, rasional, tujuan-tujuan yang realistis, berkomunikasi dengan terbuka, wajar, dan pemahaman dalam berhubungan dengan orang lain (E. M. . Berne, 1975). Model analitik Eric Berne adalah Analisis Transaksional (TA), adalah metode humanistik yang digunakan dalam psikologi, komunikasi, pengembangan, psikopatologi, pendidikan dan konseling (Akkoyun, 2001; Shirai, 2006). Pendekatan TA terdiri dari komponen-komponen berikut: ego states, transactions, strokes, scripts, life scenario, life positions and time structures (Akkoyun, 2001; E. M. . Berne, 1975; Shirai, 2006; Solomon, 2003). Penelitian ini biasanya berfokus pada status ego, konsep TA yang paling mendasar (Akkoyun, 2001; E. M. . Berne, 1975), seperti dijelaskan di bawah ini: status ego diperiksa dengan dua model terpisah, struktural dan fungsional. Menurut analisis struktural, kepribadian setiap individu dipisahkan menjadi tiga keadaan: orangtua, dewasa, dan anak-anak. menurut analisis fungsional, keadaan ego orangtua dipisahkan menjadi orangtua kritis dan orangtua asuh; status ego anak menjadi bebas dan adaptasi; dan status ego Dewasa tetap sama (Akkoyun, 2001; Drego, 2006; Solomon, 2003). Critical Parent adalah pikiran, perasaan dan kepercayaan yang dipelajari dari orangtua atau figur orangtua (Solomon, 2003). The Nurturing Parent melindungi dan menjaga (Akkoyun, 2001). Adapted Child adalah bagian dari kepribadian yang berkembang dari pesan-pesan orangtua yang dipelajari ketika tumbuh dewasa (Solomon, 2003). Konseling dalam pendekatan ini cenderung ke arah aspek-aspek kognitif dan behavioral dan dirancang untuk membantu orang-orang dalam mengevaluasi putusanputusan yang telah dibuatnya menurut kelayakan sekarang atau kelayakan masa kini.

Analisis transaksional merupakan psikoterapi transaksional yang dapat digunakan dalam konseling individual, tetapi lebih cocok digunakan dalam konseling kelompok (E. M. . Berne, 1975). Analisis transaksional pada mulanya direncanakan sebagai suatu bentuk treatment kelompok dan prosedurprosedur terapeutiknya memberikan hasil dalam setting kelompok. Dalam setting kelompok, orang-orang bisa mengamati perubahan orang lain, yang memberikan kepada mereka model-model bagi peningkatan kebebasan memilih. Mereka menjadi paham atas struktur dan fungsi kepribadian mereka sendiri serta belajar bagaimana bertransaksi dengan orang lain. Transaksi-transaksi dalam kelompok memukinkan para anggota mampu meningkatkan kesadaran, baik tentang dirinya sendiri maupun tentang orang lain dan karenanya bisa berfokus pada perubahan-perubahan dan putusan-putusan ulang yang akan mereka buat dalam kehidupan mereka (E. M. . Berne, 1975).

Harris mengemukakan bahwa treatment atas individu-individu dalam kelompok adalah metode analisis transaksional (Hidayat, 2017). Individu memandang fase permulaan kelompok analisis transaksional sebagai suatu proses mengajar dan belajar serta meletakkan kepentingannya pada peran didaktik terapis kelompok. Analisis Transaksional melibatkan suatu kontrak yang dibuat oleh klien, yang dengan jelas menyatakan tujuan-tujuan dan arah proses konseling. Analisis transaksional berfokus pada keputusan-keputusan awal yang dibuat oleh klien dan menekankan kemampuan klien untuk membuat keputusan-keputusan baru. Analisis transaksional menekankan aspek-aspek kognitif rasional-behavioral dan berorientasi kepada peningkatan kesadar sehingga klien akan mampu membuat keputusan-keputusan baru dan mengubah cara hidupnya. Berne menemukan bahwa dengan menggunakan analisis transaksional kliennya membuat perubahan signifikan dalam kehidupan mereka.

Corey (2011) menjelaskan dalam kelompok terapi analisis transaksional, peserta kelompok belajar mengenali ketiga kondisi ego orangtua, dewasa, dan anak-anak tempat mereka berfungsi. Anggota kelompok juga belajar bagaimana perilaku mereka saat ini dipengaruhi oleh peraturan dan peraturan yang mereka terima dan dimasukkan sebagai ego anak-anak dan bagaimana mereka dapat mengidentifikasi naskah kehidupan yang mereka putuskan, yang menentukan tindakan mereka. Pada akhirnya, mereka menyadari bahwa mereka sekarang dapat melakukan keputusan baru dan memulai arah baru dalam hidup, mengubah apa yang tidak bekerja sambil mempertahankan apa yang bermanfaat bagi mereka. Untuk mengubah keinginan mereka menjadi kenyataan, klien dituntut untuk secara aktif mengubah perilaku mereka.

Konseling kelompok dengan pendekatan analisis transaksional dapat meningkatkan selfacceptance dan kreativitas (Alizamar Alizamar, Afdal, Ifdil, \& Syahputra, 2019) kinerja sosial pada mahasiswa (Ciucur, 2013a, 2013b). Kondisi ini disebabkan karena setiap adanya penyimpangan perilaku ada strategi khusus untuk memperbaiki perilaku baru (Ciucur, 2013a). Maddah-Shoorcheh, Vafaei-Jahan, \& Bolghanabadi (2012) menemukan cara meningkatkan keterampilan pemecahan konflik dengan konseling kognitif dan transaksional. Hasil menunjukkan adanya pengaruh yang diberikan kelompok kognitif dan kelompok yang diberikan analisis transaksional.

Lebih lanjut, Emdady, $\mathrm{M}$ and Shafiabadi, A (2013) menemukan adanya pengaruh konseling 
kelompok dengan metode analisis transaksional dalam mempengaruhi kinerja sosial siswa, metode analisis transaksional bekerja pada skills dan komunikasi seseorang yang akurat memiliki komunikasi yang lebih baik dengan belajar pola analisis transaksional, kondisi ini membantu mereka untuk memahami suasana hati, gairah dan kecenderungan yang lebih baik dan akhirnya meningkatkan kinerja sosial mereka. Senadah dengan Voniati (2017) adanya pengaruh pemberian layanan konseling kelompok terhadap kemampuan interaksi sosial siswa yang ditandai dengan mampu dan bersedia tanggung jawab, mampu menujukkan amarah secara langsung bila tersinggung, dapat menunjukkan kasih sayang secara langsung, dapat dapat menahan emosional. Peningkatan interaksi sosial dapat membentuk dan memelihara interaksi yang berkualitas dengan keluarga, teman, dan tergantung pada kemampuan individu bertransaksi dengan ego state yang sesuai (LaBouff, Rowatt, Johnson, Tsang, \& Willerton, 2012). Namun, yang terjadi pada era millennial individu lebih cenderung bertransaksi dengan smartphone (Afdal et al., 2018), akibatnya individu tidak memiliki keterampilan komunikasi yang baik dan lebih mengarah kepada kecanduan smarpthone atau internet (Syahputra, Prayitno, Syahniar, \& Hariyani, 2019).

Pemaparan di atas menunjukan keefektifan analisis transaksional pada ranah pendidikan, berikut juga dipaparkan penggunaan pendekatan analisis transaksional pada ranah keluarga (Kazami, Taher Neshat Doost, Kajbaf, Mohammad, Abadi, Agha Mohamadi, \& Sadeghi, 2013; Nayeri, Lotfi, \& Noorani, 2014). Nayeri, Lotfi, \& Noorani (2014) mengemukakan bahwa konsep pelatihan Analisis Transaksional memiliki dampak signifikan pada peningkatan keintiman pada Pasangan dan kesan juga stabil selama 3 bulan. Hal ini sesuai dengan (Kazami et al., 2013) yang menemukan bahwa pelatihan kelompok analisis transaksional dapat meningkatkan keintiman sosial dengan meningkatkan keterampilan relasional. Senada dengan penelitian Sekhavat \& Attari (2010) yang mengindikasikan bahwa pelatihan kelompok analisis transaksional dapat meningkatkan hubungan ibu-anak dan komponen-komponennya seperti kasih sayang.

Salamat (2005) dalam sebuah penelitian menunjukkan bahwa metode analisis transaksional mengakibatkan berkurangnya konflik perkawinan. Selain itu, dalam penelitian ini ditemukan bahwa keintiman, metode interaksi, metode kritik dan kepuasan pernikahan juga meningkat. Torkan (2006) mengemukakan pengajaran analisis transaksional akan mengarah pada peningkatan kepuasan pernikahan dan keintiman. Dengan mencapai informasi tentang cara menyampaikan pesan mereka kepada pasangan mereka, dan memperoleh persepsi tentang transaksi mereka dengan pasangan mereka dan pengaruhnya terhadap mereka, para peserta dalam pelatihan kelompok telah mendapatkan interaksi yang lebih baik dan kemudian keintiman yang lebih tinggi.

Analisis transaksional memberikan pendekatan interaksional dan kontraktual kepada kelompok. Ini bersifat interaksional karena menekankan dinamika transaksi antara orang-orang, dan itu adalah kontrak di mana anggota kelompok mengembangkan pernyataan yang jelas tentang apa yang akan mereka ubah dan bagaimana mereka akan berbeda sebagai hasil kelompok. Anggota menetapkan tujuan dan arahan mereka dan menggambarkan bagaimana mereka akan berbeda ketika mereka menyelesaikan kontrak mereka. Kontrak memungkinkan untuk pijakan yang lebih setara antara klien dan terapis dan menunjukkan bahwa tanggung jawab untuk perubahan dibagi antara anggota kelompok dan terapis (Corey, 2011). Konselor menganalisis pola transaksi dalam kelompok, sehingga konselor dapat mengetahui ego state yang mana yang lebih dominan dan apakah ego state yang ditampilkan tersebut sudah tepat atau belum. Tujuan penelitian ini adalah untuk menganalisis terapi transaksional dalam seting kelompok.

\section{METODE}

Jenis penelitian ini adalah penelitian kepustakaan, yaitu serangkaian penelitian yang berkaitan dengan metode pengumpulan data perpustakaan, atau penelitian yang objek penelitiannya dieksplorasi melalui berbagai informasi perpustakaan (buku atau jurnal ilmiah) yang membahas tentang analisis transaksional dalam seting kelompok. Penelitian perpustakaan atau tinjauan pustaka adalah studi yang secara kritis memeriksa pengetahuan, ide, atau temuan yang terkandung dalam tubuh literatur berorientasi akademik (Syaodih, 2009).

\section{HASIL DAN PEMBAHASAN \\ Menggunakan TA dalam Kelompok}

Setelah pemimpin mengajar TA, dia dapat menggunakan konsep orangtua, dewasa, dan anak dalam berbagai cara ketika bekerja dengan satu anggota atau dengan seluruh kelompok. Salah satu alasan TA adalah teori yang sangat baik untuk digunakan dalam kelompok adalah bahwa TA dapat digunakan dalam berbagai cara visual dan pengalaman. Pemimpin bisa:

1. Gambarkan lingkaran PAC dalam berbagai ukuran dengan panah dari berbagai status ego pada papan tulis untuk mewakili interaksi yang dijelaskan oleh anggota yang bekerja.

2. Gambar lingkaran PAC dalam berbagai ukuran di papan tulis untuk mewakili anggota yang bekerja. 
3. Gunakan kursi (kursi anak kecil atau kursi berdiri) untuk mewakili keadaan ego Anak atau orangtua.

4. Lakukan adegan dan mintalah anggota memainkan status ego yang berbeda.

Konselor menganalisis pola transaksi dalam kelompok, sehingga konselor dapat mengetahui ego state yang mana yang lebih dominan dan apakah ego state yang ditampilkan tersebut sudah tepat atau belum. Ada tiga tipe transaksi yaitu; Komplementer, Menyilang, dan Terselubung.

1. Transaksi Komplementer (Melengkapi)

Transaksi komplementer yaitu bila stimulus yang diberikan mendapat respon yang diharapkan. Jenis transaksi ini merupakan jenis terbaik dalam komunikasi antarpribadi karena terjadi kesamaan makna terhadap pesan yang mereka pertukarkan, pesan yang satu dilengkapi oleh pesan yang lain meskipun dalam jenis sikap ego yang berbeda. Transaksi komplementer terjadi antara dua sikap yang sama yakni sikap dewasa.

Transaksi terjadi antara dua sikap yang berbeda namun komplementer. Kedua sikap itu adalah sikap orangtua dan sikap anak-anak. Komunikasi antarpribadi dapat dilanjutkan jika terjadi transaksi yang bersifat komplementer karena di antara mereka dapat memahami pesan yang sama dalam suatu makna.

2. Transaksi Menyilang

Transaksi menyilang yaitu bila respon terhadap stimulus tidak seperti yang diharapakan. Hal ini terjadi manakala pesan yang dikirimkan komunikator tidak mendapat respons sewajarnya dari komunikan. Akibat dari transaksi silang adalah terputusnya komunikasi antarpribadi karena kesalahan dalam memberikan makna pesan. Komunikator tidak menghendaki jawaban demikian, terjadi kesalahpahaman sehingga kadang-kadang orang beralih ke tema pembicaraan lain.

3. Transaksi Terselubung

Jika terjadi campuran beberapa sikap di antara komunikator dengan komunikan sehingga salah satu sikap menyembunyikan sikap yang lainnya. Sikap tersembunyi ini sebenarnya yang ingin mendapatkan respons tetapi ditanggapi lain oleh si penerima. Maksudnya adalah bila stimulus yang tampaknya dewasa seharusnya diarahkan pada dewasa. Tetapi dalam terselubung adalah menyembunyikan maksud yang sebenarnya yaitu sikap dewasanya malah justru mengarah lain bukan ke dewasa, tetapi dewasa ke anak atau orangtua ke anak. Dalam transaksi tersembunyi/terselubung ini biasanya diikuti oleh bahasa non-verbal (pergantian tinggi nada suara, ekspresi wajah, sikap badan).
Nayeri et al. (2014) melakukan penelitian Analisis Transaksional dalam setting kelompok untuk meningkatkan keintiman pasangan suami istri, pelatihan dilakukan dalam sesi 8 2- jam, Terapi dimulai dengan memperkenalkan tiga kondisi ego kepada anggota kelompok. Kemudian mereka didorong untuk menemukan keadaan dominan mereka dalam interaksi mereka yang berbeda dengan orang lain dalam situasi yang beragam. Kemudian transisi pelengkap dan lintas dijelaskan dan latihan yang cukup dan diperlukan di sekitar mereka. Setelah itu beberapa permainan yang dapat terjadi dalam kehidupan perkawinan antara pasangan ditinjau, dan dampaknya pada komunikasi pasangan diperiksa. Selama pelatihan kelompok, pasangan peserta didorong untuk menyadari cara komunikasi dan permainan yang tidak sesuai yang telah mereka terapkan. Dan mereka dibujuk untuk memutuskan untuk menerapkan kondisi ego yang tepat pada waktu yang tepat.

\section{Permasalahan Keanggotaan Kelompok}

Analisis Transaksional (TA) adalah teori komprehensif tentang perilaku manusia yang dikembangkan oleh psikiater California Eric Berne. Teori TA memiliki banyak konsep penting dan berharga, seperti skrip, coretan, dan permainan yang dapat berguna dalam kelompok. Pada bagian ini kami fokus terutama pada konsep TA dari ego state dan skrip karena mereka dapat dengan mudah diajarkan kepada anggota kelompok (Jacobs, Masson, \& Harvill, 1998).

Menurut teori TA, setiap orang memiliki tiga kondisi ego: orangtua, dewasa, dan anak. Keadaan ego ini dikembangkan sebagai hasil dari "pesan" masa kecil. Pesan seperti, "Anda adalah anak yang buruk" atau "Hanya anak-anak bodoh yang melakukan kesalahan pengambilan" atau "Jangan percaya siapa pun," dapat datang melalui komentar langsung dari orangtua atau pengasuh lainnya atau melalui pengalaman awal kehidupan. Ada dua bagian dari Parent Ego State: Critical Parent dan the Nurturing Parent. Status ego anak juga memiliki dua bagian: anak alami, bebas, atau OK dan anak yang diadaptasi atau tidak OK.

Keadaan ego mana yang dominan dalam seseorang tergantung pada pengalaman seseorang. Misalnya: Julie adalah orang yang dibesarkan oleh seorang ibu yang sangat kritis. Terlepas dari bagaimana Julie berusaha menyenangkan, ibunya selalu menyalahkannya. Ketika Julie tumbuh memasuki usia pra-remaja dan masa remajanya, dia memasukkan banyak komentar negatif yang dibuat ibunya tentang segala hal mulai dari penampilannya hingga persahabatan- 
nya. Sebagai seorang dewasa muda, Julie menggunakan penilaian ibunya seolah-olah itu adalah keyakinannya sendiri. Julie menginternalisasi komentar kritis ibunya dan mengembangkan status ego orangtua Kritisnya sendiri. Sekarang Julie mengkritik dirinya sendiri karena membuat kesalahan umum dan sering menjadi sangat marah pada kesalahan ini. Dia juga kritis terhadap orang lain dan pada kehidupan secara umum ketika hal-hal tidak berjalan baik baginya. Karena ibu Julie tidak menyampaikan banyak pesan pengasuhan, Julie kesulitan merawat dirinya sendiri atau orang lain (Jacobs et al., 1998).

Sebagai anak yang sangat muda, Julie merasakan tekanan untuk menyesuaikan diri dengan tuntutan ibunya. Karena itu, sementara Julie mengembangkan ego Kritis orangtua, dia juga mengembangkan Ego Adaptasi Anak, meminta persetujuan orang lain, takut akan ketidaksetujuan, dan menyesuaikan diri atau beradaptasi dengan situasi untuk menghindari kritik. Sekarang Julie menjalani hidupnya menggunakan status ego orangtua Kritis dan Status Ego Anak Adaptasinya, dengan anak yang mungkin kurang alami dan orangtua asuh. Yang paling penting, bagaimanapun, adalah fakta bahwa Julie tidak menggunakan status ego dewasanya, terutama dalam keputusan antarpribadi, dan mencari hubungan yang pada akhirnya kritis dan kasar. Dalam sebuah kelompok, pemimpin yang menggunakan teori ini akan mencoba membantu Julie menyadari keadaan egonya yang berbeda dan bagaimana masing-masing kondisi ego memengaruhi keputusan dan interaksinya.

Dari kondisi ini dapat dinyatakan bahwa perilaku Julie mengarah kepada perilaku agresif, perempuan lebih cenderung berperilaku agresif secara verbal dengan niat yang menyakitkan seperti; gosip, pengecualian, dan prasangka buruk (A Alizamar, Syahputra, Ardi, \& Trizeta, 2018). Untuk mengatasi perilaku agresi perlunya layanan bimbingan kelompok dengan menggunakan tampilan video untuk mengurangi perilaku agresif (Hariyani \& Syahputra, 2019). Setelah itu, diberikan pendekatan transaksional dengan setting kelompok untuk meningkatkan kemampuan interaksi sosial dengan penggunaan ego state yang sesuai (Voniati, 2017).

\section{Tahapan dan Teknik Konseling Kelompok Transaksional}

Hakikat konseling dalam pendekatan analisis transaksional yaitu perancangan status ego klien dalam bertransaksi sehingga klien mampu mempromosikan dirinya dengan tepat, serta berupaya untuk merangsang rasa tanggung jawab pribadi klien atas tingkah lakunya sendiri, pemikiran yang logis, rasional, tujuan-tujuan yang realistis, berkomunikasi dengan terbuka, wajar, dan pemahaman dalam berhubungan dengan orang lain. Konseling dengan pendekatan ini cenderung ke arah aspek-aspek kognitif dan behavior dan dirancang untuk membantu orang-orang dalam mengevaluasi putusan-putusan yang telah dibuatnya menurut kelayakan sekarang.

Menurut berne ada 5 tahapan dalam konseling transaksional (E. Berne, 1996; Widdowson, 2009), yaitu:

\section{Tahap Pertama}

Terapis mulai merenungkan dua pertanyaan berikut: 1) Apa yang saya pikir perlu dilakukan klien ini?, 2) Perubahan apa yang perlu mereka lakukan?. Setelah beri pertanyaan itu diberikan kepada klien dan dijawab secara intuitif serta tulis jawaban menggunakan kata-kata yang klien suka. Pada tahap ini, klien tidak perlu tepat. Respons dari jawaban klien untuk perubahan global, besar atau untuk perubahan kecil. Di bawah ini adalah contoh kemungkinan tanggapan terhadap pertanyaan-pertanyaan ini. Ini adalah tema yang cukup umum dan Anda mungkin dapat mengidentifikasi ini pada klien.

- Menginternalisasi rasa harga diri.

- Belajarlah bersikap asertif dengan keluarga mereka.

- Berhentilah mencoba untuk menyenangkan semua orang sepanjang waktu.

- Berhentilah merasa bersalah karena tidak sempurna.

- Berhentilah memberi diri mereka kesulitan tentang kekurangan mereka yang secara nyata

- Belajarlah untuk rileks.

\section{Tahap Kedua}

Ambil setiap item dalam daftar dan lihat bagaimana kita dapat memahami perubahan tertentu menggunakan konsep TA. Untuk mengambil contoh di atas:

- Untuk membatalkan keyakinan tentang skrip tidak baik menjadi cukup baik;

- Untuk dapat menerima, meminta dan memberikan positif pada diri sendiri (harga diri);

- Untuk membatalkan perintah tidak penting;

- Untuk menggunakan pengendalian pada transaksi orangtua, menentukan batas penggunaan transaksi orangtua;

- Untuk menghentikan grandiosity tentang menyenangkan orang lain dan melalaikan yang terkait dengan kebutuhan dan perasaan sendiri;

- Untuk berhenti beradaptasi berlebihan;

- Untuk mengganggu dan menghentikan dialog internal yang kritis antara orangtua dan anak; 
- Untuk mengembangkan penilaian diri yang realistis daripada mencari `bukti 'kepercayaan naskah;

- Untuk berhenti mengatur situasi dan permainan di mana kepercayaan skrip dikonfirmasi;

- Untuk menggunakan sumber daya orang dewasa untuk mengenali kapan saatnya untuk berhenti dan bersantai.

Anda sekarang memiliki dasar dari rencana treatmen untuk klien ini.

\section{Tahap Ketiga}

Sekarang, ambil daftar perubahan target, dan bandingkan ini dengan keinginan dan masalah yang diajukan klien. Tunjukkan jika ada item yang tidak sesuai dengan masalah klien. Perubahan target ini yang bukan bagian dari alasan klien anda untuk datang ke terapi perlu dikontrak jika mereka ingin menjadi bagian dari terapi. Ini dapat dilakukan pada tahap apa pun yang Anda rasa perlu untuk mengangkat masalah dengan klien Anda. Sisa masalah sudah dicakup oleh kontrak Anda yang sudah ada dan karenanya dapat menjadi bagian dari rencana treatmen.

4. Tahap Keempat

Mengambil daftar yang Anda kompilasi, sorot yang merupakan tiga perubahan target yang paling penting, atau prioritas. Seringkali perubahan tertentu akan membawa perubahan lain dalam diri individu. Dengan menggunakan contoh di atas, tiga perubahan target yang paling penting adalah:

- Untuk membatalkan keyakinan tentang skrip tidak baik menjadi cukup baik;

- Untuk dapat menerima, meminta dan memberikan positif pada diri sendiri (harga diri);

- Untuk membatalkan perintah tidak penting;

Dengan ketiga perubahan ini, perubahan lainnya akan lebih mudah, atau dapat terjadi secara spontan. Namun, mungkin saja perubahan lain dapat terjadi lebih cepat, misalnya dalam contoh ini, keyakinan skrip tentang tidak cukup baik kemungkinan akan menjadi masalah yang sangat dalam. Mengambil kontrol Dewasa, mengevaluasi situasi dan secara aktif menghindari situasi di mana keyakinan skrip dikonfirmasi atau bahkan mengakui dan mengubah situasi ini ketika mereka terjadi akan melemahkan kekuatan keyakinan skrip yang mendasarinya dan mungkin merupakan perubahan yang lebih realistis untuk dilakukan terlebih dahulu. Luangkan waktu untuk mencari tahu perubahan mana yang dapat terjadi terlebih dahulu. Jelajahi dalam pengawasan intervensi apa yang mungkin Anda buat untuk membantu memfasilitasi setiap perubahan target ini.

\section{Tahap Kelima}

Tunjukkan pada daftar anda yang mana dari perubahan target jangka pendek yang dapat diatasi segera, yang akan membutuhkan perhatian berkelanjutan dan mereka yang merupakan perubahan target jangka panjang, yang akan lebih tepat untuk diperkenalkan nanti dalam proses terapi. Anda sekarang memiliki rencana treatmen untuk klien anda

Tahap-tahap konseling yang dikemukan oleh (Harris, 1981) anak didik Eric Berne, proses konseling AT ada beberapa tahapan, yaitu:

1. Pada bagian pendahuluan digunakan untuk menentukan kontrak dengan klien, baik mengenai masalah maupun tanggung jawab kedua pihak.

2. Pada bagian kedua baru mengajarkan Klien tentang ego statenya dengan diskusi bersama Klien.

3. Kemudian membuat kontrak yang dilakukan oleh klien sendiri, yang berisikan tentang apa yang akan dilakukan oleh klien, bagaimana klien akan melangkah kearah tujuan yang telah ditetapkan, dan klien tahu kapan kontraknya akan habis. Kontrak bagi Dusay (Corsini, 1987) adalah berbentuk pernyataan klien - konselor untuk bekerja sama mencapai tujuan dan masing-masing terikat untuk saling bertangung jawab.

4. Setelah kontrak ini selesai, baru kemudian konselor bersama klien menggali ego state dan memperbaikinya sehingga terjadi dan tercapainya tujuan konseling.

Dalam konseling yang menggunakan pendekatan analisis transaksional digunakan Teknik tertentu. Teknik Konseling Dalam AT konseling diarahkan kepada bagaimana klien bertransaksi dengan lingkungannya. Karena itu, dalam melakukan konseling ini, konselor memfokuskan perhatian terhadap apa yang dikatakan klien kepada orang lain dan apa yang dikatakan orang lain kepada klien. Untuk itu, teknik yang sering digunakan dalam AT diantaranya adalah analisis struktur, analisis transaksional, analisis mainan dan analisis script (Widdowson, 2009).

a. Analisis Struktur

Analisis struktur maksudnya adalah analisis terhadap status ego yang menjadi dasar struktur kepribadian klien yang terlihat dari respons atau stimulus klien dengan orang lain. 
b. Analisis Transaksional

Konselor menganalisis pola transaksi dalam kelompok, sehingga konselor dapat mengetahui ego state yang mana yang lebih dominan dan apakah ego state yang ditampilkan tersebut sudah tepat atau belum.

c. Analisis Permainan

Analisis mainan adalah analisis hubungan transaksi yang terselubung antara Klien dengan konselor atau dengan Lingkungannya. Konselor menganalisis suasana permainan yang diikuti oleh klien untuk mendapat sentuhan, setelah itu dilihat apakah klien mampu menanggung resiko atau malah bergerak kearah resiko yang tingkatnya lebih rendah.

d. Analisis Skript

Analisis Skript ini merupakan usaha konselor untuk mengenal proses terbentuknya skript yang dimiliki klien. Analisis skript ini hendaknya sampai menyelidiki transaksi seseorang sejak dalam asuhan orangtua, pada masa ini terjadi transaksi antara orangtua dengan anak-anaknya. Dan pada akhirnya terbentuk suatu tujuan hidup dan rencana hidup (script atau naskah). Hal ini dilakukan apabila konselor sudah meyakini bahwasanya kliennya terjangkit posisi hidup yang tidak sehat.

Permatasari (2015) mengungkapkan tahapan layanan konseling kelompok dengan pendekatan analisis transaksional (KKAT), yaitu tahap awal (kontrak), tahap analisis struktural, tahap analisis transaksional, tahap analisis game, tahap analisis script, dan tahap akhir. Tahap-tahapan tersebut merupakan satu kesatuan dari kegiatan KKAT yang diikuti anggota kelompok dengan baik, sehingga keberhasilan pelaksanan KKAT efektif dalam menumbuhkan kerendahan hati. Setiap pertemuan dalam KKAT dipertemuan akhir selalu diberikan jurnal refleksi diri yang bertujuan sebagai alat kontrol anggota dalam pencapaian tujuan yang dituliskan dalam kontrak.

\section{PENUTUP}

Selama ini pendekatan transaksional dikenal sebagai pendekatan dalam konseling individu, kenyataannya analisis transaksional dibuat pertama kali dalam seting kelompok. Konsep dan teknik Analisis transaksional efektif diterapkan dalam sesi konseling kelompok. Analisis transaksional menyediakan pendekatan terstruktur yang memungkinkan anak-anak dan remaja untuk melihat hubungan antara apa yang mereka pelajari dalam keluarga mereka dan sikap mereka terhadap orang lain. Pemimpin kelompok TA yang kompeten menciptakan iklim di mana para anggota dapat mulai mempertanyakan sejauh mana mereka telah menerima pesan dari keluarga dan budaya mereka.
Untuk itu perlunya pengembangan layanan konseling kelompok dengan pendekatan analisis transaksional untuk membantu siswa meningkatkan keterampilan interaksi sosial, dan untuk peneliti selanjutnya lebih memfokuskan pada variable psikososial, kenapa demikian karena permasalahan psikososial berawal dari kegagalan kemonukasi yang salah dalam memainkan peran ego state yang sesuai dengan interaksi sosial.

\section{REFERENSI}

Afdal, A., Alizamar, A., Ifdil, I., Ardi, Z., Sukmawati, I., Zikra, Z., ... Hariyani, H. (2018). An Analysis of Phubbing Behaviour: Preliminary research from counseling perspective. 1st International Conference on Educational Sciences and Teacher Profession (ICETeP 2018). Atlantis Press, 295, 270-273.

Akkoyun, F. (2001). Transactional Analysis Transactional Solving Approach in Psychology. Nobel Yayıncılık, 2. Baskl, Ankara.

Alizamar, A., Afdal, A., Ifdil, I., \& Syahputra, Y. (2019). Exploration of S tudents ' Creativity Based on Demography. International Journal of Innovation, Creativity and Change, 5(1), 50-65.

Alizamar, A., Syahputra, Y., Ardi, Z., \& Trizeta, L. (2018). Differences in aggressive behavior of male and female students using Rasch stacking. International Journal of Research in Counseling and Education, 3(1), 22-32. https://doi.org/10.24036/0051za0002

Berne, E. (1996). Principles of Transactional Analysis. Indian Journal of Psychiatry, 38(3), 154-159. https://doi.org/10.1007/978-1-4899-4471-9_6

Berne, E. M. . (1975). Transactional Analysis in Psychotherapy. New York: Grove Press, Inc.

Ciucur, D. (2013a). A transactional analysis group psychotherapy programme for improving the qualities and abilities of future psychologists. Procedia-Social and Behavioral Sciences, 78, 576-580.

Ciucur, D. (2013b). The ego states and the "big five" personality factors. Procedia-Social and Behavioral Sciences, 78, 581-585.

Corey, G. (2011). Theory and Practice of Group Counseling. Canada: Nelson Education.

Corsini, R. . (1987). The concise Encyclopedia of Psychology. Canada: john Willey \& Sons.

Drego, P. (2006). Why people say and do what they don't really want to? <http:// www.lifepositive.com/Mind/psychology/transac tional-analysis/harmoniousrelationships.asp>.

Hariyani, H., \& Syahputra, Y. (2019). Whether there effect of the used video on group guidance services to aggressive behavior? Konselor, 8(3), 92-97.

Harris. (1981). Saya Oke Kamu Oke, Terjemahan. 
Yuda Syahputra, Neviyarni, Netrawati, Yeni Karneli, Hariyani

Jurnal Bimbingan dan Konseling Ar-Rahman

Volume 5, Nomor 2, Tahun 2019

e-ISSN 2477-6300

Jakarta: Yayasan Cipta Loka Caraka.

Hidayat, R. (2017). Peningkatan Aktivitas

Komunikasi Interpersonal Dalam Organisasi

Melalui Perbaikan Efikasi Diri, Kepemimpinan

Dan Kekohesifan Tim. Jurnal Manajemen

Pendidikan, 4(2), 161-170.

Jacobs, E. E., Masson, R. L., \& Harvill, R. L. (1998). Group counseling: Strategies and skills (3rd ed.). Pacific Grove, CA: Brooks/Cole.

Kazami, Z., Taher Neshat Doost, H., Kajbaf, Mohammad, Abadi, A., Agha Mohamadi, S., \& Sadeghi, S. (2013). Effectiveness of group training of transactional theory on social intimacy of in runaway girls. Socio Psychological Studies of Women, Tenth Year, 3, 139-162.

LaBouff, J. P., Rowatt, W. C., Johnson, M. K., Tsang, J. A., \& Willerton, G. M. (2012). Humble persons are more helpful than less humble persons: Evidence from three studies. The Journal of Positive Psychology, 7(1), 16-29.

Maddah-Shoorcheh, R., Vafaei-Jahan, Z., \& Bolghanabadi, M. (2012). Effectiveness of Cognitive and Transactional Analysis Group Therapy on Improving Conflict-Solving Skill. Zahedan Journal of Research in Medical Sciences, 14(1), 43-48.

Nayeri, A., Lotfi, M., \& Noorani, M. (2014). The Effectiveness of Group Training of Transactional Analysis on Intimacy in Couples. Procedia - Social and Behavioral Sciences, 152, 1167-1170.

Permatasari, D. (2015). Menumbuhkan Kerendahan Hati Siswa SMP melalui Konseling Kelompok Analisis Transaksional. Proceedings Konferensi Nasional" Mempersiapkan Kebangkitan
Generasi Emas Indonesia 2045 Melalui Revolusi Mental Anak Bangsa, 1(1), 325-343.

Salamat, M. (2005). Examine the effectiveness of relational skills teaching by using the transactional analysis method on decreasing the marital conflicts in couples of Isfahan city. MA thesis. Islamic Azad university of Roodehen.

Sekhavat, S., \& Attari, Y. (2010). Examine the effectiveness of transactional analysis approach on improving the mother- child relationship in boy students of middle schools of Dezfool city. New Findings in Psychology, 5(15), 39-56.

Shirai, S. (2006). How transactional analysis can be used in terminal care. International Congress Series. 1287, 179-184.

Solomon, C. (2003). Transactional analysis theory: basics. Transactional Analysis Journal, 33(1).

Syahputra, Y., Prayitno, P., Syahniar, S., \& Hariyani, H. (2019). Rasch stacking analysis of student internet addiction based on gender. Jurnal Konseling Dan Pendidikan, 7(1), 35-41.

Syaodih, N. (2009). Metode Penelitian Pendidikan. Bandung: Remaja Rosdakarya.

Torkan, H. (2006). Examine the effectiveness of group training of transactional analysis on marital satisfaction of Isfahan coulples. MA thesis, Isfahan university.

Voniati, N. (2017). Efektivitas Layanan Konseling Kelompok dengan Teknik Analisis Transaksional dalam Meningkatkan kemampuan Interaksi sosial Peserta Didik Tahun Ajaran 2016/2017 (Doctoral dissertation). IAIN Raden Intan Lampung.

Widdowson, M. (2009). Transactional Analysis. USA: Taylor \& Francis. 